\section{International Perspectives on Living Wages for Sustainable Livelihoods: Project Glow (Global Living Organisational Wage)}

Project GLOW

Auckland, New Zealand

\section{Definitions}

Sustainable Development This goal focuses on promoting Goal (SDG) 8 inclusive and sustainable economic growth, with productive full employment
Decent Work

and decent work for everyone (UN 2020).

According to the International Labour Organization's (ILO's) Decent Work Agenda (ILO 2020a), the concept of decent work is related to peoples' aspirations for their working lives and opportunities to engage in work, which is productive while also delivering an equitable income, job and workplace security, and social protections for workers and their families. Decent work is the enabling of social inclusion and personal development. Such work affords workers opportunities to express any workplace concerns and to organize and take part in decision-making processes that affect them and their colleagues. Central are issues of equity regardless of factors such as gender, religion, [dis]ability, ethnicity, and sexual orientation. These constituent elements of SDG 8 imply that economic growth and decent work are not
Co-authored by the following members of GLOW: Dusadee Yoelao and Kanu Priya Mohan, Behavioral Science Research Institute, Srinakharinwirot University, Bangkok, Thailand; Mendiola Teng-Calleja, Ateneo de Manila University, Philippines, and Jose Antonio R. Clemente, University of the Philippines Diliman; Molefe Maleka, TUT, Pretoria, and Ines Meyer, University of Cape Town; Harold Ames, Industrial Psychologist, Pacific Rim Hub, Hawai'i; Amanda M. Young-Hauser, Stuart C. Carr, and Darrin Hodgetts, Auckland Hub, New Zealand. 
mutually exclusive but mutually reinforcing (Carr et al. 2016).

Project GLOW We focus in this chapter on (Global Living how issues of decent work are Organisational Wage)

materializing across some of the hubs in Project GLOW's global network (Project GLOW 2020; http:// projectglow.net). The chapter showcases the diversity as well as the utility of different approaches to ensure decent work and shared prosperity in different, but interconnected, contexts. Written before

COVID-19, the chapter is also a snapshot on the world of work up to 2019, just before the pandemic broke.

\section{Introduction}

A core bridging concept in this chapter is having a sustainable livelihood (World Commission on Environment and Development [WECD], 1987). Following this Commission's work, in what was widely known as the Brundtland Report, sustainable livelihood was defined as "a means of living is sustainable which can cope with and recover from stress and shocks, maintain or enhance its capabilities and assets, and provide sustainable livelihood opportunities for the next generation; and which contributes net benefits to other livelihoods at the local and global levels and in the short and long term" (Chambers and Conway 1991, p. 6). Originally focused on environmental sustainability in rural development, the concept has since been progressively expanded, first to urban environments where most of the world's population now lives and works and then to resilience in disaster management (Krantz 2001). At the 2012 Rio Conference on Sustainable Development, it became apparent to global policy-makers that poverty reduction was a multifaceted task that included disaster management and access to jobs, alongside sustainable energy, cities, food, water, and oceans (Yiu and Saner 2014). From Rio came the United Nations' commitment to what we now know as the 2016-30 UN SDGs. As an interconnected set, these Sustainable Development Goals (SDGs) are primarily committed to "eradicating poverty in all its forms, everywhere," including through sustainable livelihoods (UN 2020).

At the turn of 2020, sustainable livelihoods were already simply not accessible to the majority of the world's working population. Unemployment remained a scourge, with over 170 million out of work (International Labour Organization [ILO] 2020a, b). Working poverty is an even bigger issue. Two-thirds of the world's workforce was engaged in work that is informal, meaning that it is unregulated, lacks social protection, is precarious, and offers low, irregular, and unlivable wages (ILO 2019). According to the ILO (2019), "A majority of the 3.3 billion people employed globally in 2018 experienced a lack of material well-being, economic security, equal opportunities or scope for human development" (p. 1). Even in formal work, a survey of 14,000 workers in 14 countries, across a range of economies, found that 59 percent were struggling to make ends meet or not coping at all (International Trade Union Confederation [ITUC] 2017). Thus, poor working conditions were the main global employment challenge (ILO 2019), and we should "protect people not [just] jobs" (World Bank 2019, parenthesis added). Today that clarion call is even more relevant than prepandemic.

The most obvious way out of working poverty is to provide people with the means to earn a decent living and realize their own inherent capabilities (Sen 1999). As Sen (1999) points out, wages are not an end in themselves, but rather an important means to an end. Minimum wages, which are legal statutes designed to protect workers from falling below poverty thresholds, no longer fulfil that function in most countries where they exist (Lenhart 2017). These wages do not even apply across many others or across the two-thirds of workers in the world whose work is informal (ILO 2019). Against this backdrop, 
living wage campaigns have proliferated across the global economy, as a new form of labor safeguard (Global Commission on the Future of Work 2019). More than just scraping by, and more than material costs of living, a living wage in principle is meant to allow people enough freedom (from economic worry and poverty traps) to dream, to aspire, and to have dignity, social participation, and protection, with hope for their own future generations (Carr et al. 2016). Thus, a living wage is consistent with the idea of a sustainable livelihood and SDG 8.

\section{The Global Living Organisational Wage Network}

Initiated in 2016 (coinciding with the introduction / incepton of the SDGs), GLOW is a pratical way of instantiating evidence-informed and informing pracites and policies with respect to livelihoodsustaining living wages. It remains focused on answering one overarching question: using purchasing power parity, "Is there a global living wage that enables people, organizations and communities to prosper and thrive?" To help connect evidence with policy, it has representatives involved with the $\mathrm{UN}$ and is founded on relationships with the following multilateral/bilateral and multisector/multinational partners:

- Asian Association of Social Psychology (AASP)

- Centre for Socio-Eco-Nomic Development (CSEND), Switzerland

- Institute for Multicultural Counseling \& Education Services (IMCES)

- International Association for Applied Psychology (IAAP)

- International Organisation of Employers (IOE)

- Massey People, Organisation, Work and Employment Research (MPOWER)

- Psychology Coalition of NGOs Accredited at the United Nations (PCUN)

- Society of Industrial and Organizational Psychology (SIOP)

- Tshwane University of Technology, South Africa
Project GLOW in 2020 has at least one hub in more than 25 countries, spanning trade routes and cities within and between them. Hubs represent interdisciplinary, cross-sector partnerships between work and social sciences, practitioners, scholars, and community groups, including professional and labor associations. Being cross-generational in focus, GLOW places a strong emphasis on building research, teaching, and service capacity in and through these hubs. It is the work of these hubs that we now turn, in order to illustrate some of the progress toward SDG 8 that GLOW has made, toward each of the targets in Table 1 (in italics). Projects still in process are also indicated (grayscale). No doubt all will continue to develop in the wake of C19.

Below offers a little more information on four case studies and the diversity of interrelated work currently being conducted in concert across the GLOW network, including Thailand, South Africa, the Philippines, and the United States.

\section{Setting Foundations for a Sufficiency Living Wage (SLW) in Thailand}

SDG 8.4 relates to the development of a "Sufficiency Living Wage," which has been picked up by the Thai hub of GLOW. A Sufficiency Living Wage aims to reflect the meaning of living wage in concurrence with the Sufficiency Economy Philosophy (SEP) of Thailand. In developing foundational research for such a wage, the Thai team initiated a qualitative research project (Yoelao et al. 2019) to examine and establish the meaning of a Sufficiency Living Wage for Thailand in dialogues with blue collar workers, which revealed two emerging themes: the first was the "sufficiency of wages," which was based on the three doctrines of the Sufficiency Economy Philosophy - moderation, reasonableness, and self-immunity - when applied to a living wage. The second implied the "psychological utility of wages," which is the perceived value of the Sufficiency Living Wage, both in tangible and intangible terms.

The research team in Thailand joined Project GLOW in 2017 and sought to explore the meaning of living wage in Thailand. Researchers have 
International Perspectives on Living Wages for Sustainable Livelihoods: Project Glow (Global Living Organisational Wage), Table 1 SDG 8: Decent Work and Economic Growth - targets, indicators, and GLOW response

\begin{tabular}{|c|c|c|}
\hline Target & Indicators & Project GLOW \\
\hline $\begin{array}{l}8.1 \text { - Sustain per capita economic } \\
\text { growth }\end{array}$ & $\begin{array}{l}8.1 .1 \text { - Annual growth rate of real } \\
\text { GDP per capita }\end{array}$ & $\begin{array}{l}\text { Does a living wage bring longer-term } \\
\text { job growth? }\end{array}$ \\
\hline $\begin{array}{l}8.2-\text { Achieve higher levels of } \\
\text { economic productivity }\end{array}$ & $\begin{array}{l}\text { 8.2.1 - Annual growth rate of real } \\
\text { GDP per employed person }\end{array}$ & $\begin{array}{l}\text { Does a living wage bring upward } \\
\text { social mobility across generations? }\end{array}$ \\
\hline $\begin{array}{l}8.3 \text { - Promote policies that support } \\
\text { productive activities and decent job } \\
\text { creation }\end{array}$ & $\begin{array}{l}\text { 8.3.1 - Promotion of informal } \\
\text { employment in non-agriculture } \\
\text { employment, by sex }\end{array}$ & $\begin{array}{l}\text { What are the benefits of informal work, } \\
\text { for workers and their families, } \\
\text { compared to formal jobs? }\end{array}$ \\
\hline $\begin{array}{l}8.4-\text { Improve global resource } \\
\text { efficiency in sustainable consumption } \\
\text { and production }\end{array}$ & $\begin{array}{l}\text { 8.4.1 - Material footprint per } \\
\text { capita and GDP } \\
\text { 8.4.2 - Domestic material } \\
\text { consumption/capita, GDP }\end{array}$ & $\begin{array}{l}\text { Bangkok, Thailand-developing the } \\
\text { Construct of "Sufficiency Living } \\
\text { Wage" (SLW) }\end{array}$ \\
\hline $\begin{array}{l}8.5-\text { Achieve full and productive } \\
\text { employment and decent work for all }\end{array}$ & $\begin{array}{l}\text { 8.5.1 - Average hourly earnings of } \\
\text { female and male employees, all } \\
\text { groups } \\
8.5 .2 \text { - Unemployment rate by } \\
\text { sex, age, and persons with } \\
\text { disabilities }\end{array}$ & $\begin{array}{l}\text { Pretoria/Cape Town, South Africa, } \\
\text { and Auckland, New Zealand/ } \\
\text { Aotearoa- } \\
\text { is there a wage threshold at which } \\
\text { quality of work life and of work } \\
\text { transforms? }\end{array}$ \\
\hline $\begin{array}{l}8.6 \text { - Reduce proportion of youth not } \\
\text { in employment, education, or training }\end{array}$ & $\begin{array}{l}\text { 8.6.1 - Proportion of youth not in } \\
\text { education, employment, } \\
\text { education, or training }\end{array}$ & $\begin{array}{l}\text { Does a living wage impact levels of } \\
\text { youth employment positively or } \\
\text { negatively? }\end{array}$ \\
\hline $\begin{array}{l}8.7-\text { Action to eradicate forced labor, } \\
\text { modern slave labor, and trafficking }\end{array}$ & $\begin{array}{l}8.7 .1-\text { Children aged } 5-17 \text { years } \\
\text { in child labor }\end{array}$ & $\begin{array}{l}\text { Does a living wage reduce the rates of } \\
\text { forced labor? }\end{array}$ \\
\hline $\begin{array}{l}8.8 \text { - Protect labor rights and secure } \\
\text { work environments for all workers, } \\
\text { including migrants and precariously } \\
\text { employed }\end{array}$ & $\begin{array}{l}\text { 8.8.1 - Frequency rates of fatal } \\
\text { and nonfatal occupational } \\
\text { injuries, by sex and migrant status } \\
8.8 .2 \text { - Increase in national } \\
\text { compliance of labor rights }\end{array}$ & $\begin{array}{l}\text { Metro Manila, Philippines - using } \\
\text { research evidence to promote worker } \\
\text { rights and close the "capability gap" } \\
\text { between indecent and decent work } \\
\text { conditions }\end{array}$ \\
\hline $\begin{array}{l}8.9-\text { By } 2030, \text { devise and implement } \\
\text { policies to promote sustainable } \\
\text { tourism that creates jobs and promotes } \\
\text { local culture and products }\end{array}$ & $\begin{array}{l}\text { 8.9.1 - Tourism direct GDP as a } \\
\text { proportion of total GDP } \\
8.9 .2 \text { - Number of jobs in tourism } \\
\text { industries as a proportion of total } \\
\text { jobs and growth rate of jobs, by } \\
\text { sex }\end{array}$ & $\begin{array}{l}\text { Honolulu, Hawai'i-living wages and } \\
\text { the promotion of sustainable } \\
\text { livelihoods in tourism by/for } \\
\text { Indigenous peoples and in Small } \\
\text { Island Developing States (SIDS) }\end{array}$ \\
\hline $\begin{array}{l}8.10 \text { - Strengthen domestic financial } \\
\text { institutions to expand access to } \\
\text { financial services for all }\end{array}$ & $\begin{array}{l}8.10 .1 \text { - No. of bank branches and } \\
\text { ATMs } \\
8.10 .2 \text { - Proportion of adults with } \\
\text { a bank account }\end{array}$ & $\begin{array}{l}\text { Does a living wage expand access to } \\
\text { financial services for business/social } \\
\text { entrepreneurs and employees? }\end{array}$ \\
\hline
\end{tabular}

Source: Adapted from UN (2020)

been exploring the meaning and application of living wage in diverse contexts; for this research the definition given by Yao et al. (2017) set the direction as it explained it as a wage level that is perceived by employees as a "step change" for enhancement in work-related and overall wellbeing. Rooting the research in the context of local culture, the research team investigated if the living wage could be examined from the lens of applying the SEP, which was developed by the late King Bhumibol Adulyadej in 1997.

The Sufficiency Economy Philosophy encourages people to follow a balanced living based on the three doctrines of moderation, reasonableness, and self-immunity, which must be applied along with the conditions of virtue and knowledge. This reflects the "middle path," a corner stone of Buddhist religion (Mongsawad 2010), which is practiced by a majority of Thai population. 
Researchers have noted that the Sufficiency Economy Philosophy has provided guidelines for balanced and sustainable living since 1997 (Wibulswasdi et al. 2012) and has been integrated in policy (Barua and Tejativaddhana 2019) and practices of the Thai people.

Some of the significant lessons learned from the research indicate that:

1. Blue-collar workers, who earn a minimum wage, expressed their aspiration for a living wage in terms of an increase in wages that could support the needs of their family.

2. The shared experience of merging the Sufficiency Economy Philosophy with the workers' desired living wage resulted in the Sufficiency Living Wage, an amount that was the same or slightly less than the Living Wage, but this amount reflected sustainable consumption.

3. The researchers have developed the scale for measuring Sufficiency Living Wage, and the preliminary analyses of this indigenous concept show positive results on some of the variables related to employee well-being.

4. As the Sufficiency Economy Philosophy is deeply embedded in Thai economic and sociocultural milieu, merging it with the call for a living wage in Thailand might show the direction for an affordable and sustainable living wage.

\section{Establishing a Living Wage Threshold at which Quality of Work Life and of Work Transforms in South Africa}

The first research was conducted in 2016 by the South African hub was a comparative study with the following sample sizes: Tshwane $(n=200)$ and Cape Town $(n=200)$. Using open-ended questions, employees who earned less than R3500 (USD 202) were disaffected and ended up taking unsecured loans to make ends meet (Maleka 2016). To escape this risk, a living wage of R10 000 (USD 577) was needed (Maleka 2017). This wage was similar to the R12 500 (USD 721) being demanded by mineworkers in the platinum belt (Dlangamadla et al. 2013). The relationship between a wage and fairness was sigmoidal, with a poverty trap threshold at or about the campaign living wage, and a transformed quality of life and work after that range (Carr et al. 2018; Nthulenyane 2019).
Within the Southern African Development Community (SADC), in 2018 another study was conducted in Namibia, South Africa, and Zimbabwe, with a combined sample size of $n=631$. The study found that macroeconomic indicators (i.e., living wage, living conditions, job security, and medical services) had a significant effect on employee engagement, job satisfaction, and organizational commitment. For example, employees in South Africa who earned better than their counterparts in Namibia and Zimbabwe had highest levels of employee engagement, job satisfaction, and organizational commitment (Maleka et al. 2019).

Beyond the SADC, a cross-national comparison between South Africa and New Zealand, involving two cities in each country, found a similar sigmoidal function linking hourly wages to work motivation, including job attitudes known to be linked to productivity (Carr et al. 2018). The gradient of the curve was steeper in South Africa, which had a higher Gini coefficient, suggesting that income inequality exacerbates poverty traps.

Reflecting the power of a network of nations working on these issues, the authors were able to also draw insights from a subsequent study conducted in New Zealand and found that household net incomes of personal wage was another moderator of the curve, with higher net incomes acting as a moderator, or buffer, for precarious personal wage (Carr et al. 2019). Working poverty was most precarious, and pernicious, for singleincome households in both countries, for example, youth in precarious forms of livelihood. For these individuals, low wages had a direct link to job attitudes and work engagement, compared to workers on slightly higher wages for whom the linkage was mediated by wage fairness (Haar et al. 2018).

In conclusion, our initial findings in South Africa (and New Zealand) are consistent with poverty theory which states that employees earning below a certain threshold are trapped in poverty (Carr et al. 2016). Moreover, there was a threshold range (Yao et al. 2017). Below this range, workers feel trapped in working poverty, while above it there was a transformation not only in quality of work life but also in job attitudes 
and other human factors linked to productivity. Hence there was a win-win living wage range, at which both workers and their households, as well as organizational groups, benefited.

\section{SDG 8.8 - Protect Labor Rights and Close the Capability Gap in the Philippines}

High poverty incidence in the Philippines heightens the importance of a living wage in critical advocacy efforts to promote a decent life for more than 43.7 million workers and their families (Gavilan 2018; NAPC 2015). The need for a living wage is further buttressed by the government's inability to provide adequate social services. Currently, the daily minimum wage in the country ranges from $\mathrm{PhP} 282$ to 537 (roughly USD5.64-10.74) depending on the location of one's workplace. The IBON Foundation, a nonprofit development organization, recommends a minimum wage rate of $\mathrm{PhP} 1,004 /$ day (USD20.08/ day) or PhP23,660/month (USD473.20/month) for those residing in the National Capital Region to cover the basic expenses of a family of five members (IBON Media 2019).

Conversations on wages in Philippine society are still focused on the idea of a "minimum," which centers on meeting basic needs, rather than promoting familial well-being more generally. The ideal situation is where the minimum wage is the same as the living wage. What workers receive should not just meet their basic needs but allow them to attain more freedom and opportunities to make choices (Carr 2013) and to function in ways that they intrinsically value (Carr et al. 2017). For example, if workers value having a comfortable home, savings, or nurturing social relationships, the wage that they receive must facilitate the achievement of these outcomes.

In determining a living wage that captures what is important to Filipinos, a group of psychologists and economists gathered survey data through systematic random sampling from 500 low-and middle-income workers in Metro Manila (Teng-Calleja et al. 2018). The study used the domains of magandang buhay (good life) derived from a national survey to measure well-being of Filipinos (Sycip et al. 2008). The dimensions of magandang buhay included housing and quality of neighborhood; employment and quality of working life; savings, wealth, and assets; social relationships; leisure and spare time activities; physical health; psychological/mental health and emotional well-being; religion and spiritual life; information and knowledge; government performance; and political participation.

The research also applied Sen's (1999) concept of "capabilities" which put forth that quality of life must be assessed based on the worker's freedom to engage in activities and attain outcomes that one values. Given this, the study gathered information on what workers perceive as important domains among the 11 dimensions of a "good life" and their perceived freedom to attain each domain.

The team applied generalized linear and nonlinear curves and used several functional form specifications to derive the rate of a living wage, including symmetric sigmoidal (logistic) and asymmetric sigmoidal (Gompertz). Findings showed that both sigmoidal specifications imply that a monthly living wage stands at around PhP23,000.00 (approximately USD460.00). This amount appears to represent what is needed by the Filipino workers to feel capable of achieving quality of life in the 11 valued life domains.

The monthly living wage identified in the study supports the findings of living wage advocates (e. g., IBON Foundation) and is more than double the minimum wage mandated by the Philippine government.

\section{SDG 8.9 - Lessons Learned from Sovereignty for Sustainable Tourism Livelihoods in Hawai'i} At its core, the right to land use is the catalyst to sustainable economic development (United Nations n.d.). In other words, land is the essence to life. Therefore, it is of great importance that decent work and economic growth fundamentally incorporate policy, which appropriately governs land use (World Tourism Organization n.d.). The Hawai'i hub sought to examine lessons learned from the overthrow of a sovereign Indigenous nation in Hawai' $i$ by the United States (U.S. National Library of Medicine n.d.) through the industrial impact of land use in tourism and its impact on a living wage. The World 
Tourism Organization (n.d.) describes tourism as a contributing factor to the well-being of communities, which includes mental health (Ames 2016). Sustainable tourism provides means to decent work, economic growth, and a living wage (World Tourism Organization n.d.).

The consultative process of the Pacific RIM Hub sought guidance from na kumu (cultural teachers) in Hawai'i who are generally kupuna or the elderly of this society. The quality of their ancestral roots can be best heard through their oral history. Additional perspectives were provided by members of the Hawai'ian Kingdom, the State of Hawai'i Executive Branch, and through Hawai'i local inhabitants' lived experiences.

In contrast, an examination of the Agua Caliente Band of Indians in Southern California utilized a deductive approach. Meaning, identified elders in their community were consulted for historical and contextual purposes. Further, members of the Palm Springs Human Rights Commission, Coachella Valley Association of Governments (CVAG), and the National Park Service helped frame this current perspective on sustainable tourism livelihood.

The Hawai'ian monarch and Indigenous system was overthrown (i.e., President Clinton apology) by the United States (National Library of Medicine n.d.), which has left many kānaka maoli (Native Hawai'ians) disenfranchised (i.e., Bayonet Constitution). This helped to promote the industrialization of the kānaka maoli laborer and further Hawai'i colonization. More recently, the United Nations Human Rights Council recognized the appalling colonial occupation of the Hawai'ian Kingdom by the United States (United Nations Human Rights Council 2018).

Today, the high cost of living and low wages make it difficult for kānaka maoli to maintain their cultural presence in the Islands of Hawai'i. For example, every US\$100 is approximately equivalent to US\$282 in Hawai'ian society (Ames 2016). It is estimated $22.5 \%$ of kānaka maoli live in poverty (U.S. Census Bureau n.d.). In contrast, from 2010 over 62,000 people moved from these islands to the continental United States (U.S. Census Bureau n.d.). This phenomenon is largely believed to be associated with the lack of land rights (i.e., policy).

In comparison, the Agua Caliente Band of Cahuilla Indians in Southern California, United States, were provided with tribal trust lands by the Department of Interior (U.S. Department of Interior Indian Affairs n.d.). Land trusts provide sovereign tribes an ability to obtain resources, perpetuate their culture, and assist their members to earn a livable wage (U.S. Department of Interior Indian Affairs n.d.). This has provided the Agua Caliente Band of Cahuilla Indians with an ability to lease land, create commerce (i.e., casinos), and create a fruitful tourism industry (me•yah•whae 2019). The Agua Caliente Band of Cahuilla Indians may be a premier example of how tourism can be leveraged to perpetuate cultural wealth into a meaningful and livable wage.

In conclusion, two examples of sovereignty were provided giving the reader some insight on how tourism can dramatically impact decent work and a livable wage. Land rights are essential in promoting economic development and human rights (i.e., United Nations Human Rights Council). Arguably, it is the quality and implementation of policy that are ultimately at the heart of perpetuating our humanity.

\section{Final Thoughts}

As noted in another contribution to this volume (Wahyuni 2019), while the SDGs are a global agenda, they also need local initiatives to be realized. Project GLOW is an attempt to close that gap between thinking global and acting local. The project is predicted to span over five generations. In this chapter it was only possible to give a glimpse of what may come, through projects already underway across the network. Nonetheless, from Table 1, we can see that inroads have been made into SDG-8 and several of its key targets and indicators. All of these focus in one way or another on sustainable livelihoods.

First, we have learned that living wages are linked not only to remuneration but also to consumption and consumer expectations about what 
is materially required for a decent quality of life and work life. In some contexts, and in the Thai case where Buddhist values are highly salient, sufficiency is an important qualifier on the living wage. Second, we have found evidence of living wage validity, in the sense that in both South Africa and New Zealand, a living wage threshold can and arguably should be reached in order to enable escape from the vicious debt cycles of working poverty traps. These can be a win-win for worker and organizational groups, particularly for single-income households and in more unequal societies. Third, the living wage can potentially help to enable a worker's freedom to engage in activities and attain outcomes that one values. Moreover, it can be measured in ways that respect local context and personal values. Finally, we learned that sovereignty and policy are at the heart of sustainable livelihoods for and by Indigenous communities, including SIDS.

It remains to be seen how GLOW will tackle and address the remaining targets and indicators in Table 1 and how COVID-19 will reshape the GLOW agenda. At present these are all projects in process or in the making. However, the lens of a living wage, and the concept of a sustainable livelihood, has much to offer to the SDGs in general, and SDG-8 in particular, in these challenging times.

\section{Cross-References}

- Supporting the Sustainable Development Goals Through Partnerships and Local Development

\section{References}

Ames HT (2016) A transcendental phenomenological study on Hawai'i tourism's impact on Nā kumu (Order No. 10140352). ProQuest Dissertations \& Theses Gelobal. (1821932259). https://search.pro quest.com/docview/1821932259? accountid $=36783$

Barua P, Tejativaddhana P (2019) Impact of application of sufficiency economy philosophy on the well-being of Thai population: a systematic review and meta-analysis of relevant studies. J Popul Soc Stud 27(3):195-219. Retrieved from https://www.tci-thaijo.org/index.php/ jpss/article/view/139845
Carr SC (2013) Anti-poverty psychology. Springer, New York

Carr SC, Parker J, Arrowsmith J, Watters PA (2016) The Living Wage: theoretical integration and an applied research agenda. Int Labour Rev 155(1):1-24. International Labour Organization: Geneva

Carr SC, Parker J, Arrowsmith J, Haar J, Jones H (2017) Humanistic management and living wages: a case of compelling connections? Humanist Manag J 1 (2):215-236

Carr SC, Maleka MJ, Meyer I, Barry ML, Haar J, Parker J et al (2018) How can wages sustain a living? By getting ahead of the curve. Sustain Sci 13(4):901-917. https:// doi.org/10.1007/s11625-018-0560-7

Carr SC, Haar J, Hodgetts D, Arrowsmith J, Parker J, Young-Hauser A, Alefaio-Tuglia S, Jones H (2019) An employee's living wage and their quality of work life: how important household size and income? J Sustain Res 1:1-19

Chambers R, Conway GR (1991) Sustainable rural livelihoods: practical concepts for the 21st century. Institute of Development Studies Discussion Paper 296. Institute of Development Studies, Surrey

Dlangamadla F, Jika T, Ledwada L, Mosamo S, Saba A, Sadiki L (2013) We are prepared to kill each other: the Marikana story. NB Publishers, Cape Town

Gavilan J (2018) In Numbers: what you need to know about the Philippine labor sector. Retrieved from https:/www.rappler.com/newsbreak/iq/201448-factslabor-sector-philippines

Global Commission on the Future of Work (2019) Work for a brighter future. ILO, Geneva

Haar J, Carr SC, Parker J, Arrowsmith J, Hodgetts D, Alefaio-Tugia S (2018) Escape from working poverty: steps toward sustainable livelihood. Sustainability 10:41-44

IBON Media (2019, April 14) Family living wage for a family of five members in NCR. Retrieved from https://www.ibon.org/family-living-wage-for-a-familyof-five-members-in-ncr/

International Labour Organization [ILO] (2019) World employment and social outlook - trends 2019. ILO, Geneva

International Labour Organization [ILO] (2020a) The 2030 development agenda. ILO, Geneva. Accessed 24 Mar 2020, from https://www.ilo.org/global/topics/sdg2030/goal-8/lang\%2D\%2Den/index.htm

International Labour Organization [ILO] (2020b) Decent work. ILO, Geneva. Accessed 24 Mar 2020, from https:/www.ilo.org/global/topics/decent-work/lang\% 2D\%2Den/index.htm

International Trade Union Confederation [ITUC] (2017) ITUC Global Poll. Ankar Solutions, Brussels

Krantz L (2001) The sustainable livelihood approach to poverty reduction: an introduction. Swedish International Development Cooperation Agency (SIDA), Stockholm 
Lenhart O (2017) The impact of minimum wages on population health: evidence from 24 OECD countries. Eur J Health Econ 18:1031-1039

Maleka MJ (2016) Narratives of employees visiting Tshwane mall who earn above and below an estimated living wage. In: GBATA conference proceedings in October 2016

Maleka MJ (2017) Exploring the relationship between a living wage and human resources outcomes: evidence from Tshwane Marabastad Mall. In: GBATA conference proceedings in Austria

Maleka MJ, Mpofu M, Hlatywayo N, Meyer I, Carr S, Parker J (2019) Employee engagement, organizational commitment and job satisfaction in Namibia, South Africa, and Zimbabwe: an exploratory study. J Psychol Afr 29(4):393-400. https://doi.org/10.1080/ 14330237.2019 .1647964

Me•yah•whae (2019) The Magazine of the Agua Caliente Band of Cahuilla Indians. Retrieved from https:// flipbook.pub/me-yah-whae/2019-fall-winter/

Mongsawad P (2010) The philosophy of sufficiency economy: a contribution to a theory of development. Asia Pac Dev J 17(1):123-143

National Anti-Poverty Commission (2015) Poverty count. Retrieved from http://www.napc.gov.ph/?q=articles/ poverty-count

Nthulenyane T (2019) Employees' perceptions about how a living wage relates to human resources management outcomes at an engineering company, proposal approved late in 2016 and looking for approval letter from a company, M-Tech Human Resources Management Tshwane University Technology (Research based)

Project GLOW (Global Living Organisational Wage) (2020) Project GLOW. Auckland. http://projectglow. net/

Sen A (1999) Development as freedom. Random, New York

Sycip L, Asis MM, Luna E (2008) The measurement of Filipino well-being: findings from the field. In: Paz CJ (ed) Ginhawa, kapalaran, dalamhati: essays on Well-being, opportunity/destiny and anguish. University of the Philippines Press, Quezon City, pp 13-29

Teng-Calleja M, Bertulfo DJ, Clemente JA, Menguito ML (2018) Why the clamor for higher wages is justified. Retrieved from https://www.rappler.com/thoughtleaders/203593-reasons-clamor-higher-minimum-wagejustified
U.S. Census Bureau (n.d.) Fact finder. Retrieved from https://factfinder.census.gov/

U.S. Department of Interior Indian Affairs (n.d.) Fee to Trust. Retrieved from https:/www.bia.gov/bia/ots/feeto-trust

U.S. National Library of Medicine (n.d.) Native people's concepts of health and illness: President Clinton's apologizes for the 1893 overthrow of Hawai'ian monarch. Retrieved from https://www.nlm. nih.gov/nativevoices/timeline/578.html

United Nations (n.d.) Sustainable Development Goals: knowledge platform. Retrieved from https://sustainable development.un.org/

United Nations (UN) (2020) Sustainable Development Goals Knowledge Platform. Accessed 24 Mar 2020, from https://sustainabledevelopment.un.org/sdg8

United Nations Human Rights Council (2018) Memorandum: the case of Mme Routh Bolomet.Retrieved from https:// hawaiiankingdom.org/blog/united-nations-acknowledgesthe-occupation-of-the-hawaiian-kingdom/

Wahyuni D (2019) Supporting the sustainable development goals through partnerships and local development. In: Leal Filho W et al (eds) Partnerships for the Goals, Encyclopaedia of the UN sustainable development goals. https://doi.org/10.1007/978-3319-71067-9 10-1

Wibulswasdi C, Piboolsravut P, Pootrakool K (2012) Sufficiency economy philosophy and development, 5 th edn. The Crown Property Bureau, Bangkok, Thailand. ISBN: 978-974-8259-21-5

World Bank (2019) 2019 world development report. World Bank, Washington, DC

World Commission on Environment and Development (1987) Our common future. WCED, New York

World Tourism Organization (n.d.) Sustainable Development. Retrieved from https://www.unwto.org/ sustainable-development

Yao C, Parker J, Arrowsmith J, Carr SC (2017) The living wage as an income range for decent work and life. Empl Relat 39(6):875-887. https://doi.org/10.1108/ER-032017-0071

Yiu L, Saner R (2014) Sustainable development goals and millennium development goals: an analysis of the shaping and negotiation process. Asia Pac J Public Adm 36:89-107

Yoelao D, Mohan KP, Sombatwattana P (2019) A qualitative construction of sufficiency living wage in Thailand based on the sufficiency economy philosophy. Int Perspect Psychol Res Pract Consult 8(4):227-239. https://doi.org/10.1037/ipp0000117 